Original Research Paper

\title{
Sosialisasi Pengawasan Partisipatif Bagi Pemilih Pemula Pada Pilkada Di Kabupaten Sumbawa
}

\author{
Edy Kurniawansyah $^{1^{*}}$, Bagdawansyah Alqadri ${ }^{1}$

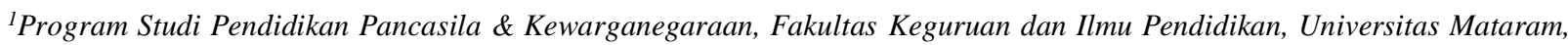 \\ Mataram, Indonesia
}

DOI: https://doi.org/10.29303/jpmpi.v4i2.848

Sitasi: Kurniawansyah. E., \& Alqadri, B. (2021). Sosialisasi Pengawasan Partisipatif Bagi Pemilih Pemula Pada Pilkada Di Kabupaten Sumbawa. Jurnal Pengabdian Magister Pendidikan IPA, 4(2)

\author{
Article history \\ Received: 30 April 2021 \\ Revised: 23 Mei 2021 \\ Accepted: 30 Juni 2021 \\ *Corresponding Author: Edy \\ Kurniawansyah, Program Studi \\ Pendidikan Pancasila \& \\ Kewarganegaraan, Fakultas \\ Keguruan dan Ilmu Pendidikan, \\ Universitas Mataram, Mataram, \\ Indonesia; \\ Email: \\ edykurniawansyah@unram.ac.id
}

Abstract: Sebagai Negara yang menganut sistem demokrasi, Pemilu menjadi suatu keniscayaan. Undang-Undang Dasar (UUD) Negara Republik Indonesia tahun 1945, pasal 22E menjadi dasar penyelenggaraan Pemilu di Indonesia. Pelaksanaan pengawasan pemilu yang demokratis, tentu tidak hanya dilaksanakan secara mutlak oleh Badan Pengawas Pemilu (Bawaslu) Pusat dan Badan Pengawas Pemilu Daerah. Pemilu demokratis membutuhkan peran partisipasi masyarakat pada semua proses tahapan penyelenggaraan pemilu, termasuk peran partisipasi masyarakat dalam pengawasan pelaksanaan pemilu itu sendiri. Kegiatan pengabdian pada masyarakat ini dilakukan dengan tujuan agar para pemilih pemula mengerti dan memahami pentingnya pengawas partisipatif pada pilkada di kabupaten Sumbawa. Solusi dari terjadinya pelanggaran pemilu adalah dengan adanya pengawas partisipatif, maka akan dapat membantu dan meringankan tugas lembaga pengawas dalam mengawal peserta demokrasi yang berlangsung, hal ini dilakukan demi terwujudnya pemilu yang jujur, adil, bersih dan berintegritas. Kemudian Lembaga pengawas pemilu harus memberikan pelatihan dan bimbingan yang intensif kepada pengawas partisipatif agar mereka mengetahui dan memahami betul akan tugas dan tanggung jawab dalam mengawal pesta demokrasi. Target luaran setelah kegiatan pengabdian ini selesai adalah terpolanya pengetahuan dan pemahaman tentang pentingnya pengawasan partisipatif pada pilkada di kabupaten Sumbawa. Metode pelaksanaan kegiatan adalah sosialisasi atau penyuluhan dan FGD. Metode sosialisasi atau penyuluhan digunakan untuk memberikan informasi tentang pentingnya pengawasan partisipatif pada pilkada di kabupaten Sumbawa. Sedangkan Focus Group Discussion digunakan dalam rangka mencari solusi atas pelanggaran pada setiap pilkada di kabupaten Sumbawa. Hasil\&Pembahasan bahwa kegiatan ini berjalan dengan lancer mulai dari tahapan perencanaan sampai pada tahapan pelaksanaan, pada tahap perencanaan dilakukan mulai dengan tahapan koordinasi dengan ketua Bawaslu Sumbawa, rekrutmen anggota sapai pada tahapan analisis kebutuhan. Kemudian pada tahapan pelaksanaan mulai dari kegiatan sosialisasi dengan penyampaian materi tentang pentingnya pengawasan partisipatif sampai pada tahapan diskusi untuk mencari solusi atas pokok persoalan sesaui dengan permasalahan yang disampaiakan. Kesimpulan dengan adanya pengawas partisipatif pada pilkada di kabupaten Sumbawa akan memberikan kesadaran bagi para pelaku politik, penyelenggara pemilu dan stakeholder untuk menjaga diri, menjaga marwah partainya sehingga akan tetap berada pada relnya sesuai dengan porsinya masing-masing, sehingga dengan demikian melahirkan suatu pemilu kada yang jujur, adil dan berintegritas baik dari segi proses maupun hasilnya.

Keywords: Pengawas Partisipatif, Pemilih Pemula dan Sumbawa 


\section{Pendahuluan}

Sebagai Negara yang menganut sistem demokrasi, Pemilu menjadi suatu keniscayaan. UndangUndang Dasar (UUD) Negara Republik Indonesia Tahun 1945, pasal 22E menjadi dasar penyelenggaraan Pemilu di Indonesia. Di Indonesia pergantian kekuasaan dilaksanakan secara periodik lima tahunan melalui pemilihan umum (Pemilu). Pemilu tersebut dilakukan untuk memilih anggota Legislatif, Presiden dan Wakil Presiden, maupun Pemilihan Kepala Daerah, yakni Gubernur dan Wakil Gubernur, serta Bupati dan Wakil Bupati/Walikota dan Wakil Walikota.

Demokrasi merupakan sistem politik yang memberikan ruang bagi keadilan dan persamaan bagi semua warga negara. Sistem ini menjadi pilihan paling populer yang digunakan negaranegara di dunia. Dalam sistem negara demokrasi, pemilihan umum yang selanjutnya disingkat 'Pemilu' merupakan salah satu indikator dan tolak ukur penting pelaksanaan. Hampir semua negara di dunia melaksanakan kegiatan 'Pemilu' sebagai wahana untuk memberikan kesempatan pada masyarakat dan elite kekuasaan melakukan sirkulasi dan rekrutmen untuk berbagai jabatan jabatan kekuasaan politik dan pemerintahan baik di lembaga legislatif (DPR RI, DPD RI, DPRD Provinsi dan DPRD Kabupaten/Kota), lembaga eksekutif (Presiden/Wakil Presiden, Gubernur/Wakil Gubernur, Walikota/Wakil Walikota dan Bupati/Wakil Bupati) secara periodik 5 (lima) tahun sekali.

Kegiatan pengawasan pemilu menjadi bagian penting dalam proses pelaksanaan pemilu. Pengawasan pemilu dilakukan baik oleh lembaga penyelenggara pemilu yakni Badan Pengawas Pemilu (Bawaslu) dari semua tingkatannya, juga dilakukan masyarakat dan lembaga pemerhati atau pemantau pemilu. Undang-Undang Nomor 7 Tahun 2017 tentang Pemilihan Umum Pasal 89 ayat (1) menyatakan : pengawasan penyelenggaraan pemilu dilakukan oleh Bawaslu yang terdiri atas Bawaslu, Bawaslu Provinsi dan Bawaslu Kabupaten/Kota, Panwaslu Kecamatan, Panwaslu Desa/Kelurahan, Panwaslu LN dan Pengawas TPS.

Pengawasan pelaksanaan pemilu di Indonesia secara kelembagaan ditetapkan sejak berlakunya Undang-Undang Nomor 12 Tahun 2003 tentang Pemilihan Umum Anggota Dewan Perwakilan Rakyat, Dewan Perwakilan Daerah dan Dewan Perwakilan Rakyat Daerah. Lembaga pengawasan ini kemudian dikuatkan kembali dengan dibentuknya lembaga pengawasan pemilu yang bersifat tetap berdasarkan Undang-Undang Nomor 22 Tahun 2007 tentang Penyelenggara Pemilu dengan dibentuknya sebuah lembaga tetap yang dinamakan Badan Pengawas Pemilu (Bawaslu). Namun demikian, Bawaslu sebagai badan formal yang bertugas untuk mengawasi seluruh tahapan penyelenggaraan pemilu, masih mengalami berbagai kendala pengawasan.

Salah satu contoh masalah yang terkait dengan kendala pengawasan adalah adanya pelanggaran pilkada serentak 2015 sebagaimana dikemukakan oleh Peneliti Perkumpulan untuk Pemilu dan Demokrasi (Perludem), Khairunnisa Nur Agustiyati, bahwa dari keseluruhan tahapan pilkada serentak 2015 ditemukan 140 pelanggaran yang terbagi ke dalam lima kategori diantaranya kekerasan pelaksanaan pilkada, logistik pilkada, pelanggaran pidana dalam pelaksanaan pilkada, pelanggaran administrasi dan sengketa pencalonan. Pelanggaran pidana merupakan pelanggaran terbanyak dengan ditemukannya 54 temuan. Urutan kedua adalah logistik dengan 36 temuan, salah satu bentuk pelanggarannya adalah tidak disebarkannya undangan pemilihan formulir C6 untuk pemilih. Urutan ketiga adalah pelanggaran administrasi dengan 25 temuan, sedangkan pelanggaran kekerasan di urutan keempat dengan 13 temuan, dan sengketa pencalonan berada di urutan terakhir dengan 12 temuan. (Pasaribu, 2015).

Pengawasan terhadap penyelenggaraan Pemilu/Pemilihan merupakan suatu kehendak yang didasari keprihatinan luhur, demi tercapainya Pemilu yang berkualitas. Suatu Pemilu/Pemilihan yang dijalankan tanpa mekanisme dan iklim pengawasan yang bebas dan mandiri, maka akan menjadikan Pemilu sebagai proses pembentukan kekuasaan yang sarat dipenuhi dengan berbagai segala kecurangan.

Dalam situasi demikian itu, Pemilu telah kehilangan legitimasinya dan Pemerintahan yang dihasilkan pun sesungguhnya juga tidak memiliki legitimasi pula. Ketika berangkat dari pemahaman demikian, dan dalam rangka menjamin tercapainya Pemilu/Pemilihan yang berkualitas dan demokratis, maka menurut hemat penulis tentu kita harus menjadikan pengawasan itu sebagai suatu kebutuhan dasar, karena pengawasan merupakan keharusan, bahkan merupakan elemen yang melekat pada setiap Pemilu baik nasional maupun 
lokal. Pengawasan Partisipatif merupakan bagian dari manifestasi kedaulatan rakyat dan penguatan partisipasi politik masyarakat.

Pelaksanaan pengawasan pemilu yang demokratis, tentu tidak hanya dilaksanakan secara mutlak oleh Badan Pengawas Pemilu (Bawaslu) Pusat dan Badan Pengawas Pemilu Daerah. Pemilu demokratis membutuhkan peran partisipasi masyarakat pada semua proses tahapan penyelenggaraan pemilu, termasuk peran partisipasi masyarakat dalam pengawasan pelaksanaan pemilu itu sendiri. Pada umumnya, mereka yang menggunakan hak pilihnya sebagai Pemilih Pemula (berusia 17 tahun/pernah menikah) belum memiliki informasi dan pemahaman yang cukup mengenai Pemilu/Pemilihan. Hal tersebut cukup wajar karena mereka sebagai pemilih pemula belum memiliki pengalaman dalam pelaksanaan Pemilu/Pemilihan. Sehingga hal tersebutlah menjadi sesuatu yang sangat urgent untuk disosialisasikan dalam upaya penyuksesan Pemilu/Pemilihan serta memberikan kesejahteraan kepada masyarakat untuk kedepannya. Keterlibatan masyarakat dalam pengawasan pemilu melalui pemantauan pemilu dan lain-lain menjadi sangat penting sebagai komponen informasi bagi masyarakat umum, peserta dan penyelenggara pemilu terkait proses pelaksanaan pemilu.

Pengawasan pemilu oleh masyarakat menjadi bagian penguatan pelaksanaan pemilu yang demokratis, dimana dengan adanya pemantauan yang dilakukan oleh komponen masyarakat secara terlembaga, akan menjadi bahan penyeimbang kegiatan pelaksanaan pemilu yang dilakukan peserta pemilu dan lembaga penyelenggara pemilu resmi seperti KPU dan Bawaslu. Dengan keterlibatan masyarakat pada kegiatan pengawasan Pemilu secara langsung, maka masyarakat dapat mengikuti dinamika politik yang terjadi dan secara tidak langsung belajar tentang penyelenggaraan Pemilu dan semua proses yang berlangsung. Bagi penyelenggara Pemilu, kehadiran pengawasan masyarakat yang masif akan mengawal dan mengingatkan mereka untuk senantiasa berhati-hati, jujur dan adil dalam penyelenggaraan pemilu (Badan Pengawas Pemilu 2017: 2).

Permasalahan yang dihadapi terkait dengan pentingnya pengawasan partisipatif bagi pemilih pemula pada pilkada di kabupaten Sumbawa. Kegiatan pengabdian pada masyarakat ini dilakukan yaitu agar pelajar dan mahasiswa di
Kabupaten Sumbawa dapat memahami tentang pentingnya pengawas partisipatif pada Pilkada di kabupaten Sumbawa. Kegiatan pengabdian ini bermanfaat untuk meningkatkan pengetahuan pelajar dan mahasiswa di Kabupaten Sumbawa tentang pentingnya pengawas partisipatif pada pilkada di kabupaten Sumbawa.

\section{Metode}

Pemecahan masalah dalam kegiatan pengabdian ini akan ditempuh dengan menggunakan pendekatan/metode sebagai berikut:

\section{Sosialisasi/Penyuluhan}

Metode Sosialisasi/penyuluhan digunakan untuk memberikan informasi atau pengetahuan dan pemahaman kepada para pemilih pemula tentang pentingnya pengawasan partisipatif pada pilkada di kabupaten Sumbawa.

\section{Focus Group Discussion (FGD)}

Selain itu pendekatan/metode Focus Group Discussion (FGD) digunakan dalam rangka mencari solusi atau upaya untuk mencegah terjadinya pelanggaran pada pemilukada serta peran penting pengawas partisipatif pada pilkada di kabupaten Sumbawa.

\section{Hasil dan Pembahasan}

Kegiatan pengabdian kepada masyarakat di kabupaten Sumbawa dilaksanakan sejak 1 Agustus sampai dengan tanggal 30 Agustus 2020 dalam bentuk sosialisasi/penyuluhan dan Focus Group Discussion (FGD). Kegiatan tersebut dapat dilaksanakan dengan lancar sesuai dengan jadwal yang direncanakan. Untuk lebih jelasnya mengenai pelaksanaan kegiatan dimaksud dan hasil yang dicapai dapat dicermati dari setiap kegiatan yang telah dilaksanakan sebagai berikut:

\section{Kegiatan Perencanaan/persiapan}

Kegiatan yang dilaksanakan pada tahap perencanaan/persiapan meliputi:

\section{a. Koordinasi dengan Bawaslu Kabupaten Sumbawa}

Kegiatan ini diawali dengan pemberitahuan kepada Ketua Bawaslu kabupaten Sumbawa mengenai kegiatan pelaksanaan pengabdian dengan tema "

Sosialisasi Pengawasan Partisipatif pada Pilkada Sumbawa". Rencana kegiatan tersebut disambut baik oleh Ketua Bawaslu Sumbawa.

\section{b. Rekrutmen peserta}

Rekrutmen peserta dilakukan dalam rangka memperoleh sejumlah peserta yang akan dilibatkan 
dalam kegiatan pengabdian kepada masyarakat yaitu para pelajar dan mahasiswa di kabupaten Sumbawa. Mengingat keterbatasan anggaran dalam pelaksanaan pengabdian masyarakat ini, maka tim pengabdian membatasi jumlah peserta yang akan mengikuti kegiatan.

\section{c. Identifikasi Kebutuhan}

Identifikasi kebutuhan adalah bagian dari tahapan kegiatan persiapan yang tidak kalah penting dalam kegiatan pengabdian kepada masyarakat. Hal ini disebabkan ketersediaan berbagai kebutuhan yang diperlukan menjadi bagian yang sangat penting agar dapat terlaksananya kegiatan dengan lancar. Adapun kebutuhan yang teridentifikasi dalam kegiatan pengabdian tersebut adalah berupa perlengkapan kegiatan seperti tempat, kursi, meja, LCD, Sound system, konsumsi dan narasumber.

\section{Kegiatan Pelaksanaan}

Kegiatan yang dilaksanakan adalah penyuluhan/sosialisasi dan FGD. Penyuluhan/sosialisasi dilaksanakan dalam rangka memberikan informasi tentang pentingnya pengawasan partisipatif pada pilkada di kabupaten Sumbawa. Kegiatan penyuluhan ini memberikan manfaat yang positif dalam rangka meningkatkan pengetahuan para pemilih pemula terkait dengan pentingnya pengawasan partisipatif pada pilkada di kabupaten Sumbawa. Sementara itu FGD dilaksanakan dalam rangka menjaring berbagai masukan atau pandangan terkait upaya yang ditempuh untuk mencegah terjadinya pelanggaran pemilu oleh pengawas partisipatif pada pilkada di kabupaten Sumbawa. Untuk lebih jelasnya mengenai pelaksanaan kedua kegiatan tersebut (penyuluhan dan FGD) dapat dijelaskan sebagai berikut:

\section{a. Sosialisasi/Penyuluhan}

Pelaksanaan kegiatan dibuka oleh ketua Bawaslu Sumbawa kemudian dilanjutkan dengan penyampaian materi (Gambar 1). Adapun materi yang disampaikan adalah sebagai berikut:

\section{Pengawasan}

Menurut Sondang P. Siagian sebagaimana dikutip oleh (Nurkinan, 2018), pengertian pengawasan adalah "proses pengamatan dari pelaksanaan seluruh kegiatan organisasi untuk menjamin agar semua pekerjaan yang sedang dilakukan berjalan sesuai dengan rencana yang telah ditentukan sebelumnya". Sementara (Schermerhorn 2013) berpendapat bahwa: "controlling is the process of measuring performance and taking action to ensure desired results". Pengawasan Pemilu adalah kegiatan mengamati, melihat, mencatat dan mengkaji hasil amatan, kemudian memeriksa kesesuaian aturan dan menilai benar atau salah serta konsekuensi proses penyelenggaraan Pemilu.

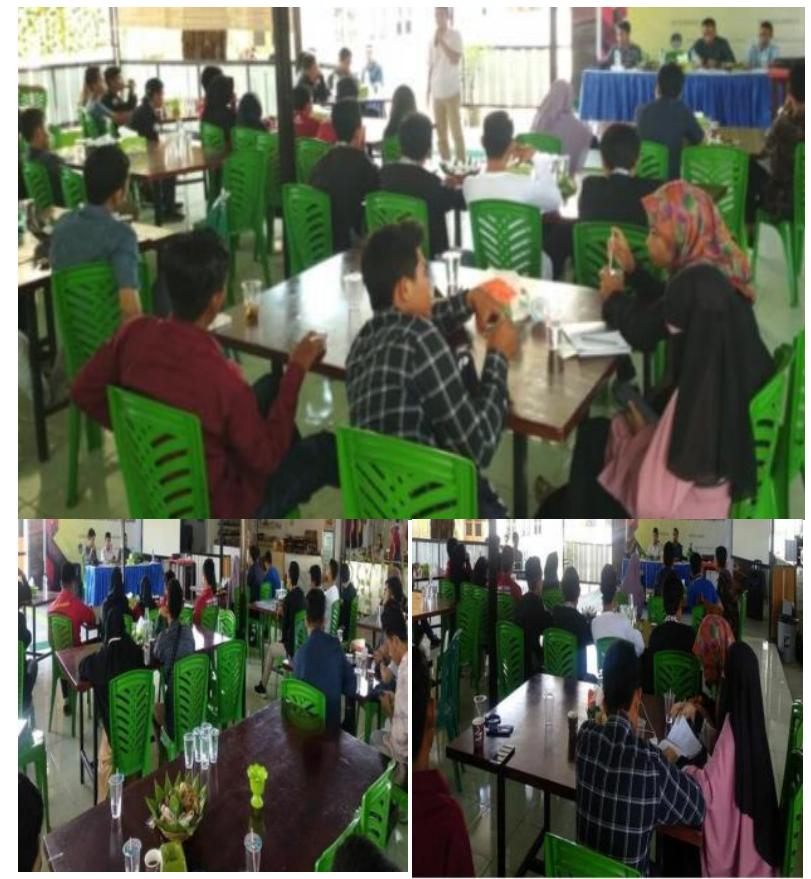

Gambar 1. Penyampaian Sosialisasi/Penyuluhan

\section{Pengawasan Partisipatif}

Adapun yang menjadi dasar pembentukan pengawas partisipatif adalah sebagai berikut:

1. Adanya penambahan pemilih pemula dengan potensi besar yang akan memilih Golput. Bawaslu menyimpulkan bahwa masih terdapat problem pemahaman mengenai prosedur Pemilu \& rendahnya kesadaran pemilih pemula untuk berpartisipasi dalam pelaksanaan pemilu.

2. Untuk mengoptimalkan pencapaian pengawasan partisipatif dengan upaya penyamaan persepsi diantara para stakeholder \& sekaligus meningkatkan kesadaran untuk berani melaporkan indikasi pelanggaran pelaksanaan tahapan Pemilu.

3. Untuk pendidikan politik sehingga masyarakat tidak alergi terhadap parpol dengan menimbulkan kesadaran masyarakat untuk berpartisipasi dalam seluruh tahapan pelaksanaan Pemilu.

4. Memperkenalkan Bawaslu pada masyarakat agar dapat mengenal \& memahami tugas Bawaslu serta bersedia mendukung kerja-kerja Bawaslu dalam menjalankan tugas pengawasan Pemilu.

Kemudian tujuan terbentuknya pengawas partisipatif adalah sebagai berikut:

1. Mewujudkan pengawasan penyelenggaraan Pemilu yang berintegritas dan berkredibilitas;

2. Mengupayakan dukungan secara optimal dari lembaga pemerintah dan OMS dalam penyelenggaran Pemilu; 
3. Mendorong partisipasi masyarakat \& media massa dalam penyelenggaran pengawasan Pemilu; dan

4. Mendukung pemberdayaan lembaga-lembaga independen dalam melaksanakan kegiatan pemantauan penyelenggaraan Pemilu dan pendidikan pemilih.

Prinsip-prinsip umum yang harus dimiliki adalah sebagai berikut:

1. Saling menghormati, tanpa paksaan, bermanfaat kedua belah pihak \& transparan akuntabel;

2. Tidak menimbulkan ketergantungan, terencana \& terukur, kepastian hukum;

3. Proporsional, profesional, efektif \& efisien.

Adapun yang menjadi prinsip-prinsip pelaksanaannya adalah sebagai berikut:

1. Kejelasan tujuan \& hasil yang diperoleh dari kerjasama;

2. Saling menghormati, membutuhkan \& menguntungkan;

3. Dikerjakan oleh petugas yang memahami konsep, teori \& proses serta berpengalaman dalam kerjasama;

4. Melibatkan berbagai pihak yang dipandang perlu \& berkepentingan secara proaktif;

5. Dapat dipertanggungjawabkan secara internal \& eksternal;

6. Dilaksanakan secara berkala \& berkelanjutan;

7. Berbasis indikator kinerja, efektif \& efisien;

8. Bersifat kelembagaan.

Bentuk-bentuk Pengawasan Partisipatif adalah sebagai berikut:

a) Ikut memantau pelaksanaan Pemilu;

b) Melakukan kajian terhadap persoalan ke-Pemiluan;

c) Ikut mencegah terjadinya pelanggaran;

d) Menyampaikan laporan pelanggaran Pemilu;

e) Menyampaikan informasi dugaan pelanggaran Pemilu;

f) Mendukung ketaatan peserta \& penyelenggara Pemilu terhadap ketentuan peraturan perundangundangan;

g) Peran-peran lainnya.

Pentingnya pengawasan partisipatif dalam mengawal pemilu yang demokratis, yang dapat tercapai apabila:

1. Bawaslu, pemantau pemilu dan masyarakat yang dilibatkan dalam pengawasan tahapan penyelenggaraan pemilu harus bersifat independen dan benar-benar tidak memihak (imparsial) salah satu satu calon / partai politik peserta pemilu sehingga tidak adanya diskriminasi terhadap siapapun.

2. Sosialisasi secara masif dan intensif dilakukan oleh Bawaslu untuk membangun kesadaran masyarakat bahwa mereka mempunyai kewajiban untuk mengawal hak pilihnya dalam pemilu dengan cara berpartisipasi dalam pengawasan tahapan penyelenggaraan pemilu dan juga terhadap lembaga-lembaga terkait pemantauan pemilu agar mereka ikut mengawasi tahapan penyelenggaraan pemilu bukan hanya pada hari pemungutan suara saja melainkan mulai proses hingga hasil;

3. Sinergitas antara Bawaslu dengan Komisi Pemilihan Umum dan pihak terkait dalam Hal Pengawasan Seperti Penertiban kampanye dan alatalat peraga kampanye.

Dengan adanya peranan aktif dari Bawaslu, Lembaga-lembaga pemantau pemilu dan juga masyarakat dalam mengawasi pemilu, akan memberikan kesadaran bagi para pelaku politik, penyelenggara pemilu dan stakeholder terkait untuk menjaga diri, menjaga marwah partainya sehingga akan tetap berada pada relnya sesuai dengan porsinya masing-masing, yang pada akhirnya akan melahirkan suatu pemilu yang jujur, adil dan berintegritas baik dari segi proses maupun hasilnya.

\section{B. Pentingnya Pengawas Pemilu}

Badan Pengawas Pemilu (Bawaslu) adalah lembaga penyelenggara Pemilu yang bertugas mengawasi penyelenggaraan Pemilu di seluruh wilayah Negara Kesatuan Republik Indonesia. Pengawas penyelenggaraan Pemilu dilakukan oleh Bawaslu, Bawaslu Provinsi, Panwaslu Kabupaten/ Kota, Panwaslu Kecamatan, Pengawas Pemilu Lapangan dan Pengawas Pemilu Luar Negeri.

Pemilihan Umum adalah sarana pelaksanaan kedaulatan rakyat yang dilaksanakan secara langsung, umum, bebas, rahasia, jujur \& adil dalam Negara Kesatuan Republik Indonesia berdasarkan Pancasila \& Undang-Undang Dasar Negara Republik Indonesia Tahun 1945. Penyelenggaraan Pemilu Anggota DPR, DPD \& DPRD telah dan akan memasuki tahapantahapan yang sangat krusial, yakni penetapan DPT, pengadaan \& distribusi logistik Pemilu, kampanye serta pemungutan \& penghitungan suara.

Sesuai dengan amanah yang diatur dalam UU No. 15 Tahun 2011 tentang Penyelenggara Pemilu \& UU No. 8 Tahun 2012 tentang Pemilu Anggota DPR, DPD \& DPRD, Bawaslu memiliki kewenangan untuk melakukan pengawasan terhadap penyelenggaraan tahapan Pemilu. Untuk mengoptimalkan pencapaian tujuan sebagaimana tersebut di atas, tentunya perlu pemantapan pengelolaan kegiatan kerjasama pengawasan dengan Organisasi Masyarakat Sipil (OMS) \& Perguruan Tinggi (PT) serta sosialisasi pengawasan pemilu bagi media massa dan ormas di masing-masing provinsi untuk meningkatkan Pengawasan Partisipatif dengan: 
Adapun pembagian Pemilu pada setiap pesta demokrasi antara lain:

1. Pemilu Anggota DPR, DPD dan DPRD, pemilu ini sering disebut oleh masyarakat sebagai Pemilu Legislatif (Pileg);

2. Pemilu Presiden dan Wakil Presiden, pemilu ini kerap disebut oleh masyarakat sebagai Pilpres; dan

3. Pemilu Gubernur, Bupati \& Walikota.

Tujuan Umum dari Pengawasan adalah sebagai berikut:

a) Menegakkan integritas, kredibilitas penyelenggara, transparansi penyelenggaraan \& akuntabilitas hasil Pemilu;

b) Mewujudkan Pemilu yang demokratis;

c) Memastikan terselenggaranya Pemilu secara langsung, umum, bebas, rahasia, jujur, adil \& berkualitas, serta dilaksanakannya peraturan perundang-undangan mengenai Pemilu secara menyeluruh.

Strategi Pengawasan dalam pemilu adalah pertama, Pencegahan terhadap potensi pelanggaran dengan melakukan tindakan, langkah-langkah \& upaya optimal mencegah secara dini terhadap potensi pelanggaran. Kedua, Penindakan terhadap dugaan pelanggaran dengan melakukan tindakan penanganan secara cepat \& tepat terhadap temuan dan/ atau laporan dugaan pelanggaran Pemilu. Tugas pengawas pemilu adalah sebagai berikut:

1. Mengawasi Perencanaan dan Penetapan Jadwal Tahapan Pemilu

2. Mengawasi Tahapan:

a. Pemutakhiran Data Pemilih dan Penetapan Data Pemilih;

b. Pencalonan dan Penetapan Anggota DPR, DPD, DPRD Provinsi dan DPRD Kabupaten/Kota;

c. Pelaksanaan kampanye

3. Mengawasi Pelaksanaan Putusan Pengadilan Terkait dengan Pemilu

4. Memantau atas Pelaksanaan Tindak Lanjut Penanganan Pelanggaran pidana Pemilu oleh Instansi yang Berwenang.

Adapun Indikator-indikator yang menjadi Kualitas Pemilihan umum adalah sebagai berikut:

1. Penyelenggara Pemilu yang Adil

2. Tingginya Partisipasi Pemilih \& Cerdas dalam Menggunakan Hak Pilihnya

3. Demokratisasi Internal Partai

4. Terpilihnya Wakil Rakyat yang Bertanggungjawab

5. Terpilihnya Pemimpin yang mendorong Pemerintahan yang Bersih.

Pemilu merupakan sarana demokrasi untuk memilih pemimpin pemimpin yang diharapkan dapat menjadi teladan bagi masyarakat. Pemilu diselenggarakan dengan partisipasi masyarakat. Adapun yang menjadi Mitra Kerjasama dalam pengawasan pemilu antara lain:

1. OMS, baik di Provinsi maupun Kabupaten/Kota;

2. PTN maupun PTS; 3. SMA/ MA/ sederajat;

3. Media Massa.

Alasan diperlukannya Kerjasama Pengawasan Pemilu pada setiap pilkada adalah sebagai berikut:

1. Alasan Subyektif: keterbatasan personil;

2. Alasan Obyektif:

a) wilayah pengawasan yang sangat luas;

b) Rasio personil pengawas Pemilu dengan jumlah wilayah administrasi pemerintahan tidak berimbang

\section{b. Focus Group Discussion (FGD)}

Kegiatan dari Focus Group Discussion (FGD)

(Gambar 2) memperlihatkan hasil berbagai gagasan atau pendapat terkait dengan pengawasan partisipatif pada pilkada di kabupaten Sumbawa. Setelah seluruh rangkaian kegiatan penyuluhan dilakukan, diketahui bahwa adanya faktor pendukung dan faktor penghambat selama kegiatan berlangsung.

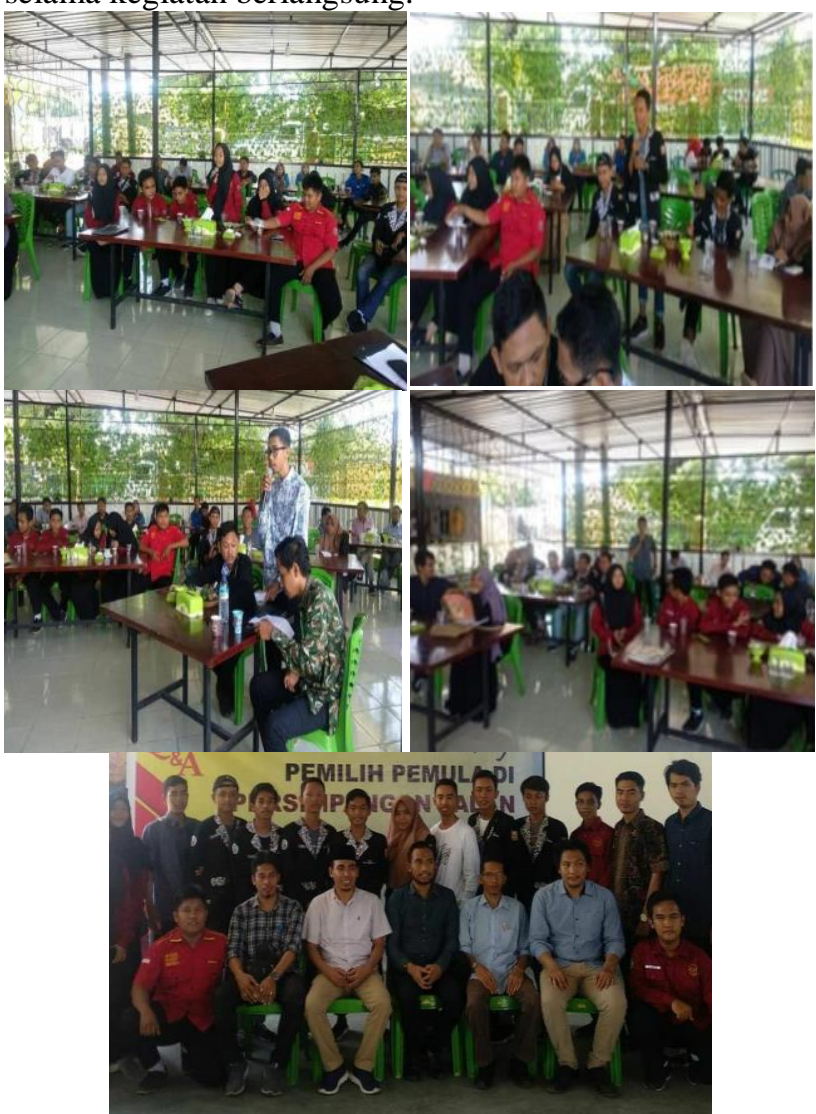

Gambar 2. Focus Group Discussion (FGD) dengan peserta sosialisasi

Adapun faktor-faktor pendukung dalam kegiatan pengabdian ini, adalah sebagai berikut: 
1. Adanya dukungan dari Ketua Bawaslu Sumbawa dan dan unsur pimpinan lainnya termasuk kasek dan para staf pegawai setempat dalam pelaksanaan kegiatan pengabdian mulai dari persiapan pelaksanaan sampai selesainya kegiatan pengabdian dilaksanakan.

2. Adanya dukungan dan partisipasi dari peserta yang luar biasa sehingga kegiatan ini bias dilaksanakan.

3. Materi penyuluhan ini sangat relevan dengan kondisi.

4. Beberapa pihak terkait yang turut mendukung pelaksanaan kegiatan sejak perencanaan hingga selesainya laporan ini.

Sedangkan faktor penghambat dalam kegiatan pengabdian ini, di antaranya:

1. Kegiatan ini tidak dapat dilaksanakan sesuai dengan waktu yang direncanakan karena para peserta yang datang terlambat. Penyuluhan direncanakan di mulai pukul 09.00 namun warga siswa datang jam 09.30.

2. Tempat pelaksanaan kegiatan ini di aula perusda Sumbawa dan sarana yang tersedia juga terbatas.

\section{Kesimpulan}

Dari hasil kegiatan Sosialisasi/penyuluhan dan FGD yang telah dilaksanakan dapat ditarik kesimpulan sebagai berikut:

1. Kegiatan penyuluhan ini terlaksana dengan baik karena didukung oleh beberapa faktor pendukung, walaupun dalam prakteknya terdapat faktor penghambat, namun hal itu tidak menjadi penghalang untuk pelaksanaan kegiatan.

2. Penyampaian materi dengan menggunakan metode sosialisasi atau penyuluhan dan FGD mendapat respon yang sangat positif dari peserta yang hadir karena materi yang disampaikan sangat berkaitan dengan pentingnya pengawasan partisipatif pada pilkada Sumbawa.

3. Berbagai masukan dan idea gagasan dari peserta yang mengikuti kegiatan, akan dijadikan sebagai pertimbangan dalam upaya mencegah terjadinya pelanggaran pemilu atau paling tidak meminimalisir terjadinya pelanggaran

\section{Ucapan Terima Kasih}

Pada kesempatan yang ini, kami mengucapakan terima kasih yang menadalam atas bantuan, dukungan dan kerjasama kepada ketua dan kelurga besar Bawaslu Sumbawa yang telah menjadi mitra dalam kegiatan pengabdian kepada masyarakat melalui kegiatan Sosialisasi/penyuluhan pentingnya pengawasan partisipatif bagi pemilih pemula pada pilkada di kabupaten Sumbawa.

Kemudian ucapan terima kasih pula kami sampaikan kepada segenap peserta atas waktu dan dukungan yang telah mengikuti selama proses kegiatan berlangsung. Semoga kegiatan ini bermanfaat bagi kita semua.

\section{Daftar Pustaka}

Arrsa Ria Casmi, 2014. "Pemilu Serentak Dan Masa Depan Konsolidasi Demokrasi”, Jurnal Konstitusi, Vol. 11 No. 3.

Nurkinan, "Peran Partisipasi Masyarakat Dalam Pengawasan Pemilihan Umum Serentak Anggota Legislatif Dan Pilpres Tahun 2019”, Jurnal Politikom Indonesiana, Vol. 3 No. 1, Juli 2018, hlm. 34.

Ria Casmi Arrsa, "Pemilu Serentak Dan Masa Depan Konsolidasi Demokrasi”, Jurnal Konstitusi, Vol. 11 No. 3, September 2014, hlm. 517.

Schermerhorn, 2013, 12th Management, United State of America, John Wiley \& Sons, Inc, p.12.

Solihah, R dkk, 2018. "Pentingnya Pengawasan Partisipatif Dalam Mengawal Pemilihan Umum Yang Demokratis", Jurnal Wacana Politik, Vol. 3 , No. 1 .

Suswantoro, G. (2016). Pengawasan Pemilu Partisipatif. Penerbit: Erlangga. Undang-Undang Nomor 42 Tahun 2008 tentang tentang Pemilihan Umum Presiden dan Wakil Presiden.

Undang-Undang Dasar Negara Republik Indonesia 1945.

Wibawa, kadek. "Pengawasan Partisipatif untuk Mewujudkan Good Governance dalam Penyelenggaraan Pemilihan Umum Serentak di Indonesia". Adminitrative Law \& Governance Journal. Volume 2 Issue 4, Nov 2019.

Yukrisna, Tity dkk, "Pengawasan Partisipatif Masyarakat Dalam Pemilihan Umum Serentak Presiden/Wakil Presiden Dan Pemilihan Umum Legislatif Tahun 2019 di Kabupaten Kapuas". Pencerah Publik, Volume 7 Issue 2, April 2020 Undang-Undang Nomor 7 Tahun 2017 Tentang Pemilihan Umum. 